\title{
Pola Asuh Anak dalam Keluarga Pemulung
}

\author{
Inayati Ma'rifah, Cut Dhien Nourwahida, Andri Noor Adriansyah \\ UIN Syarif Hidayatullah Jakarta, Indonesia \\ E-mail: Cut.dhien@uinjkt.ac.id
}

\begin{abstract}
The study of child care in the family scavenger in Jurang Mangu Timur South Tangerang. The goal is to find out how this kind of upbringing applied parents who work as scavengers. The research method using qualitative methods, and the type of research is descriptive. Researchers took the data by interviewing, observation and documentation. Informant was a parent who worked as scavengers and their children aged 4-12 years old. The results showed that parenting in a family scavenger leads to authoritarian upbringing. That pattern of care that have rigid rules in raising children. Each violation subject to physical punishment, verbal and psychological. Rarely praise or reward obtained when children obey this parents. Few or never existed to justify the praise children's behaviour. when they implement the rules. Low income levels have influenced parenting applied to the scavenger families. Income earned by only family scavenger Rp.400.000.00 until Rp600.000.00 every month, because of a low income, they even employ their children find stuff. They do not spoil the child, and also rare to spoil a child.
\end{abstract}

Keywords: parenting; children; family; scavengers

Abstrak. Studi pengasuhan anak di pemulung keluarga di Jurang Mangu Timur Tangerang Selatan. Tujuannya adalah untuk mengetahui bagaimana cara pengasuhan yang diterapkan orangtua yang bekerja sebagai pemulung. Metode penelitian menggunakan metode kualitatif, dan jenis penelitiannya adalah deskriptif. Peneliti mengambil data dengan wawancara, observasi dan dokumentasi. Informan adalah orang tua yang bekerja sebagai pemulung dan anak-anak mereka yang berusia 4-12 tahun. Hasil penelitian menunjukkan bahwa mengasuh anak dalam pemulung keluarga mengarah pada pengasuhan yang otoriter. Itulah pola asuh yang memiliki aturan kaku dalam membesarkan anak. Setiap pelanggaran dikenakan hukuman fisik, verbal dan psikologis. Jarang pujian atau hadiah didapat saat anak-anak mematuhi orang tua ini. Beberapa atau tidak pernah ada untuk membenarkan perilaku pujian anak-anak. Ketika mereka menerapkan aturan. Tingkat pendapatan yang rendah telah memengaruhi pola asuh yang diterapkan pada keluarga pemulung. Penghasilan yang diperoleh hanya oleh pemulung keluarga Rp.400.000,00 hingga Rp600.000,00 setiap bulan, karena penghasilan yang rendah, mereka bahkan mempekerjakan anak-anak mereka mencari barang. Mereka tidak memanjakan anak, dan juga jarang memanjakan anak.

Kata Kunci: pengasuhan anak; anak-anak; keluarga; pemulung

Permalink/DOI: https://doi.org/10.15408/harkat.v14i1.10400 


\section{Pendahuluan}

Keluarga merupakan media sosialisasi pertama yang dialami oleh seorang individu. Keluarga biasanya terdiri dari seorang ayah, ibu dan anak yang terikat dalam ikatan darah. Di dalam sebuah keluarga orang tua sangat berperan penting dalam mendidik, membimbing, juga menjadi teladan bagi seorang anak. Dari orang tua anak mendapat pendidikan moral dan spiritual.

Anak pada dasarnya meneladani sikap dari orang tuanya, oleh karena itu sikap dan watak dari seorang individu pertama kali dibentuk oleh orang tua. Orang tua juga memberikan sosialisasi kepada anak tentang aturan dan norma-norma yang ada di masyarakat.

Orang tua sudah seharusnya memberikan pengasuhan yang baik bagi anak. Karena sudah menjadi tanggung jawab orang tua mendidik dan melindungi anak. Tetapi sayangnya masih banyak orang yang menjalani peran orang tua tanpa kesadaran pengasuhan. Pengasuhan yang mereka terapkan bersifat kaku dan keras. Anak dituntut untuk mengikuti semua kemauan orang tuanya, sehingga anak tidak memiliki kebebasan, karena semua hal dikendalikan oleh orang tua.

Hukuman diberikan kepada anak bila tidak patuh. Situasi ini dapat menjadi peluang terjadinya tindak kekerasan pada anak (Sri Lestari, 2012:38). Hukuman baik fisik maupun non fisik akan mempengaruhi kepribadian seorang anak. Seseorang yang sering mengalami hukuman fisik akan menjadi pribadi yang penentang dan pembangkang.

Pada umumnya semua hukuman fisik menimbulkan bahaya bagi tubuh. Akibatnya, hukuman itu berubah menjadi suatu tindakan balas dendam, pelampiasan dan kemarahan. Akhirnya hukuman pun tidak bernilai baik. Dengan memberikan hukuman fisik yang keras secara tidak langsung telah mengajarkan kepada anak nilai-nilai yang tidak pantas, seperti anti toleransi, keras, kasar, merespon kesalahan dengan perbuatan aniaya dan pukulan (John W Santrock, 2007:172). Sehingga anak anak pun akan mencontoh perbuatan kasar orang tuanya. Mereka akan melakukan hal tersebut kepada teman teman dan orang orang disekitar mereka.

Perlakuan yang salah terhadap anak juga berupa penelantaran pendidikan yang mencakup pembiaran kebiasaan bolos, dan tidak mendaftarkan anak ke sekolah, serta tidak memenuhi kebutuhan pendidikan khusus anak (John W Santrock, 2007:172).

Seperti halnya dalam pengasuhan anak pada keluarga miskin, ada orang tua yang menuntut anaknya untuk bekerja. Padahal itu merupakan kewajiban orang tua untuk mencari nafkah. Orang tua memiliki peraturan yang harus dipatuhi oleh anak. Apabila anak tidak patuh atas apa yang diperintahkan maka anak akan di beri hukuman. Ini semua demi kepentingan orang tua itu sendiri. Bahkan ada beberapa orang tua yang tidak terlalu mementingkan pendidikan sekolah untuk anaknya. Padahal pendidikan sangat penting untuk bekal anak di masa depan.

Di Kecamatan Pondok Aren Tangerang Selatan terdapat sebuah pemukiman pemulung yaitu di Jalan Pesantren Kampung Ceger RT 01 RW 03 Jurang Mangu Timur. Setelah peneliti melakukan penelitian pendahuluan dengan wawancara ketua RT setempat yang bernama Ibu Suryani yang berusia 42 tahun pada tanggal 12 Oktober 2015. Peneliti memperoleh informasi bahwa di kampung pemulung tersebut terdapat 20 Kepala keluarga dari satu blok pemukiman tersebut.

Umumnya masyarakat kampung pemulung tersebut adalah masyarakat pendatang bukan masyarakat asli setempat. Menurut Ibu Suryani pemulung tersebut sering membawa anak anaknya ikut bekerja bersamanya. Setelah peneliti melakukan pengamatan selama 2 hari bahwa lokasi tempat tinggal mereka sepi di siang 
harinya. Hal ini dikarenakan orang tua yang membawa anaknya untuk bekerja, ada yang memulung dan ada pula yang mengemis.

Berdasarkan penelitian pendahuluan, hasil wawancara peneliti dengan Ibu Sumini yang berusia 45 tahun, mereka merasa kesulitan dalam mengasuh anak mereka. Hal ini karena faktor ekonomi yang sangat memprihatinkan. Karena pendapatan mereka yang sebulan hanya mendapat hasil 400.000 rupiah saja. Mereka pun tidak memanjakan anak anak mereka "mau dimanjain gimana mbak, kalo mau dimanjain kan kudu ngelawan duit, kalo ga ada duit kan boro boro ngemanja anak. Anak anaknya kan kalo minta duit ga ada kan nangis, yang ada malah anaknya yang digebukin" kata Ibu Sumini.

Dalam sebuah keluarga idealnya ayah sebagai pencari nafkah, pelindung, pendidik dan pemberi rasa aman terhadap keluarganya. Sedangkan ibu berperan sebagai pengasuh, pendidik, dan pembimbing anak-anaknya. Pada Keluarga Pemulung tersebut terlihat bahwa mereka membawa anaknya bekerja sebagai pemulung bahkan mengemis. Padahal dalam keluarga, idealnya adalah ayah sebagai seorang suami dari istri yang seharusnya mencari nafkah dan bekerja. Seharusnya anak hanya di fokuskan pada pendidikan.

\section{Menurut Undang Undang Nomor 3} Tahun 1997 tentang pengadilan anak bahwa "anak adalah bagian dari generasi muda sebagai salah satu sumber daya manusia yang merupakan potensi dan penerus cita cita perjuangan bangsa, yang memiliki peranan strategis dan mempunyai ciri dan sifat khusus, memerlukan perlindungan dan pembinaan dalam rangka menjamin pertumbuhan dan perkembangan fisik, mental dan sosial secara utuh, serasi, selaras dan seimbang" (Undang Undang No 3 Tahun 1997).

Pada keluarga pemulung hubungan keluarga bersifat kaku dan keras. Hukuman akan diberikan kepada anak jika tidak mematuhi peraturan yang dibuat orang tua. Bahkan mereka bisa melakukan tindak kekerasan jika kemauan anak tidak sesuai dengan keinginan orang tua. Dalam hal ini peneliti tertarik untuk mengadakan penelitian tentang pola asuh anak dalam keluarga pemulung.

Menurut Kusdwiyarti Keluarga adalah kelompok orang yang terdapat hubungan darah atau perkawinan. Orang orang yang termasuk keluarga adalah ibu, bapak dan anak anaknya. termasuk keturunan suami dan isteri. Keluarga mempunyai fungsi untuk berkembang biak, mensosialisasi Keluarga merupakan tempat yang penting bagi perkembangan anak secara fisik, emosi, spiritual dan sosial. Karena keluarga merupakan sumber bagi kasih sayang, perlindungan dan identitas bagi anggotanya. Keluarga menjalani fungsi yang penting bagi keberlangsungan masyarakat dari generasi ke generasi. Menurut Berns, keluarga memiliki lima fungsi dasar yaitu

a) Reproduksi, keluarga memiliki tugas untuk mempertahankan populasi yang ada di dalam masyarakat.

b) Sosialisasi atau edukasi, keluarga menjadi sarana untuk transmisi nilai keyakinan, sikap, pengetahuan, keterampilan, dan teknik dari generasi sebelumnya ke generasi yang lebih muda.

c) Penugasan peran sosial, keluarga memberikan identitas pada para anggotanya seperti ras, etnik, religi, sosial ekonomi, dan peran gender.

d) Dukungan ekonomi, keluarga menyediakan tempat berlindung, makanan dan jaminan kehidupan.

Dukungan emosi atau pemeliharaan, keluarga memberikan pengalaman interaksi sosial yang pertama bagi anak. Interaksi yang terjadi bersifat atau mendidik anak, dan 
menolong serta melindungi yang lemah (Kusdwirarti Setiono, 2011:24).

Definisi keluarga sendiri, menurut Bunga Rampai adalah "wadah dimana sejak dini para warga masyarakat di kondisikan dan di persiapkan untuk kelak dapat melakukan peranan peranannya dalam dunia orang dewasa. Keluarga ibarat jembatan yang menghubungkan individu yang berkembang dengan kehidupan sosial dimana ia sebagai orang dewasa kelak harus melakukan peranannya"(Bunga Rampai, 1999: 284).

Menurut Kamus Besar Bahasa Indonesia pola berati "corak, model, sistem, cara, bentuk (struktur) yang tetap." Asuh yang berarti "mengasuh, satu bentuk kata kerja yang bermakna menjaga (merawat dan mendidik), membimbing (membantu, melatih) supaya dapat berdiri sendiri. Memimpin (mengepalai), dengan pemeliharaan, perawatan, dukungan dan bantuan sehingga orang tetap berdiri dan menjalani hidupnya seccara sehat."

Syaiful Bahri mendefinisikan bahwa Pola asuh orang tua adalah upaya orang tua yang konsisten dan persisten dalam menjaga dan membimbing anak sejak dilahirkan hingga remaja. Pola asuh orang tua adalah pola yang diterapkan pada anak dan bersifat relatif konsisten dari waktu ke waktu. Pola perilaku ini dapat dirasakan oleh anak dan bisa memberi efek negatif maupun positif (Syaiful, 2014:50).

Walaupun masalah spesifik yang dihadapi orang tua berubah ketika anak tumbuh besar, pada setiap tingkatan usia orang tua menghadapi berbagai pilihan tentang seberapa besar mereka harus merenspon kebutuhan anak seberapa besar kendali yang harus diterapkan.dan bagaimana menerapkannya. Sejak tahun 1970 an, para ahli perkembangan telah menyusun dimensi yang lebih tepat dari pengasuhan yang baik (John W, 2007:166-167).
Adapun menurut Elizabeth B Hurlock menjelaskan jenis jenis pola asuh sebagai berikut

a) Otoriter, dalam pola asuhan ini orang tua memiliki kaidah kaidah dan peraturan peraturan yang kaku dalam mengasuh anaknya. Setiap pelanggaran dikenakan hukuman. Sedikit sekali atau tidak pernah ada pujian yang membenarkan tingkah laku anak apabila mereka melaksanakan aturan tersebut.

b) Demokratis, orang tua menggunakan diskusi, penjelasan dan alasan alasan yang membantu anak agar mengerti mengapa ia diminta untuk mematuhi suatu aturan. Orang tua menekankan aspek pendidikan ketimbang aspek hukuman. Hukuman tidak pernah kasar dan hanya diberikan apabila anak dengan sengaja menolak perbuatan yang harus ia lakukan. Apabila perbuatan anak sesuai dengan apa yang patut ia lakukan, orang tua memberi pujian. Orang tua yang demokratis adalah orang tua yang berusaha untuk menumbuhkan kontrol dari dalam diri anak sendiri.

c) Permisif, orang tua bersikap membiarkan atau mengizinkan setiap tingkah laku anak, dan tidak pernah memberikan hukuman kepada anak. Pola ini ditandai oleh sikap orang tua yang membiarkan anak mencari dan membiarkan sendiri tata cara yang memberi batasan batasan dari tingkah lakunya. Pada saat terjadi hal yang berlebihan barulah orang tua bertindak. Pada pola ini pengawasan menjadi sangat longgar (Bunga Rampai, 1999: 52).

Pengertian anak menurut Undang Undang Nomor 3 Tahun 1997 tentang pengadilan anak bahwa:

Anak adalah "bagian dari generasi muda sebagai salah satu sumber daya manusia yang 
merupakan potensi dan penerus cita cita perjuangan bangsa, yang memiliki peranan strategis dan mempunyai ciri dan sifat khusus, memerlukan perlindungan dan pembinaan dalam rangka menjamin pertumbuhan dan perkembangan fisik, mental dan sosial secara utuh, serasi, selaras dan seimbang" (Undang Undang RI no.3 1997)

Berdasarkan Peraturan Menteri Sosial RI No. 8 Tahun 2012 tentang Pedoman Pendataan dan Pengelolaan Data Penyandang Masalah Kesejahteraan Sosial dan Sumber Kesejahteraan Sosial pemulung adalah "orang yang melakukan pekerjaan dengan cara memungut dan mengumpulkan barang bekas yang berada di beberapa tempat pemukiman penduduk, pertokoan dan pasar pasar yang bermaksud untuk didaur ulang atau dijual sehingga memiliki nilai ekonomis."

Pemulung adalah bentuk aktivitas dalam mengumpulkan bahanbahan bekas dari berbagai lokasi pembuangan sampah yang masih bisa dimanfaatkan untuk mengawali proses penyalurannya ke tempat-tempat produksi (daur ulang). Aktivitas tersebut terbagi ke dalam tiga klasifikasi diantaranya, agen, pengepul, dan pemulung.

Agen, pengepul, dan pemulung merupakan satu kesatu yang saling berkaitan dan tidak dapat dipisahkan dalam proses produksi daur ulang sampah, karena mereka saling membutuhkan satu sama lain. Jika dilihat tempat pemulung bekerja sangat tidak memenuhi standar kesehatan dan lingkungan terkesan kumuh, faktor yang ikut menentukan seseorang bekerja sebagai pemulung antara lain adalah tingkat pendidikan yang rendahserta keterbatasan pada modal maupun skill yang mereka miliki (Indra Taufik, 2013).

\section{Metode}

Pada penelitian ini peneliti menggunakan metode kualitatif deskriptif. Menurut Sugiyono "metode penelitian kualitatif adalah metode penelitian yang digunakan untuk meneliti pada kondisi objek yang alamiah, dimana peneliti adalah sebagai instrumen kunci, teknik pengumpulan data dilakukan secara triangulasi” (Sugiyono,2014:1). Dengan menggunakan metode ini peneliti akan dapat mendeskripsikan secara lebih rinci mengenai pola pengasuhan anak pada keluarga pemulung. Karena metode kualitatif itu dilakukan secara intensif peneliti ikut berpartisipasi di lapangan, mencatat secara hati hati apa yang terjadi, melakukan analisis reflektif terhadap berbagai dokumen yang ditemukan di lapangan, dan membuat laporan penelitian secara mendetail (Sulistyaningsih, 2011:109). Observasi ini dilakukan untuk mengamati keadaan lingkungan kampung pemulung, aktivitas dari keluarga pemulung, hubungan sosial keluarga pemulung dengan warga sekitar, hubungan antara orang tua dan anak dari keluarga pemulung dan perilaku anak dari keluarga pemulung. Menurut Sugiyono, "wawancara merupakan pertemuan dua orang untuk bertukar informasi dan ide melalui tanya jawab, sehingga dapat dikonstruksikan makna dalam satu topik tertentu" (Sugiyono, 2012:319). Depth interview atau wawancara mendalam yang dilakukan untuk memperoleh jawaban yang lebih luas dan untuk memperoleh informasi yang dilakukan secara mendalam terhadap masyarakat setempat (Sugiyono, 2012:319).

Menurut Moloeng, wawancara adalah "percakapan dengan maksud tertentu. Percakapan dilakukan oleh dua pihak, yaitu pewawancara (interviewer) yang mengajukan pertanyaan dan terwawancara (interview) yang memberikan jawaban atas pertanyaan tersebut" (Haris H, 2012:118). 
Dengan demikian melakukan wawancara atau interview pada prinsipnya merupakan usaha untuk menggali keterangan yang lebih mendalam dari sebuah kajian dari sumber yang relevan berupa pendapat, kesan, pengalaman pikiran dan sebagainya. Dalam penelitian ini peneliti mewawancarai Ketua RW 01 Jurang Mangu Pondok Aren Tangerang Selatan, Ketua RT 003, 5 orang tua dari keluarga pemulung, dan anak dari keluarga kampung pemulung yang berusia 4-12 tahun.

Teknik ini merupakan penelaah terhadap referensi referensi yang berhubungan dengan fokus permasalahan penelitian. Dokumen dokumen yang dimaksud adalah dokumen pribadi, dokumen resmi, referensi referensi, foto foto, rekaman kaset. Data ini dapat bermanfaat bagi peneliti untuk menguji, menafsirkan bahkan untuk meramalkan jawaban dari fokus penelitian, dalam penelitian kualitatif studi dokumentasi, peneliti dapat mencari dan mengumpulkan data data teks atau image.

\section{Hasil dan Pembahasan}

Pola asuh orang tua adalah cara orang tua dalam menjaga, mendidik dan merawat anaknya sejak dilahirkan hingga remaja. Setiap anak dilahirkan memerlukan perawatan, pemeliharaan, dan pengasuhan untuk mengantarkannya menuju kedewasaan. Pembentukan jiwa anak sangat di pengaruhi oleh cara pengasuhan anak sejak dia dilahirkan. Tumbuh kembang anak diperlukan perhatian yang serius terutama pada masa sensitif anak yaitu balita. Hasil penelitian yang didapat oleh penulis dari sepuluh informan selaku orang tua dan anak dari keluarga pemulung adalah sebagai berikut:

\section{Sistem Kerja Pemulung}

Pemulung adalah bentuk aktivitas dalam mengumpulkan bahanbahan bekas dari berbagai lokasi pembuangan sampah yang masih bisa dimanfaatkan untuk mengawali proses penyalurannya ke tempattempat produksi (daur ulang). Aktivitas tersebut terbagi ke dalam tiga klasifikasi diantaranya, agen, pengepul, dan pemulung (Indra Taufik, 2013).

Agen, pengepul, dan pemulung merupakan satu kesatu yang saling berkaitan dan tidak dapat dipisahkan dalam proses produksi daur ulang sampah, karena mereka saling membutuhkan satu sama lain. Jika dilihat tempat pemulung bekerja sangat tidak memenuhi standar kesehatan dan lingkungan terkesan kumuh, faktor yang ikut menentukan seseorang bekerja sebagai pemulung antara lain adalah tingkat pendidikan yang rendahserta keterbatasan pada modal maupun skillyang mereka miliki (Indra Taufik, 2013).

Berdasarkan temuan di lapangan peneliti memperoleh informasi bahwa sistem kerja pemulung adalah system cara pemulung mendapatkan uang dari hasil mereka menjual barang-barang hasil buangan. Pada pagi hari aktivitas keluarga pemulung ini bekerja mencari barang pulungan mulai dari pukul 09.00 WIB dengan membawa karung dan gerobak. Pukul 12.00 WIB barulah mereka kembali kerumah dengan membawa hasil pulunganya. Lokasi di Kampung Pemulung ini sepi di pagi hari karena orang tua yang membawa anaknya bekerja memulung.

Berikut ini merupakan tahap-tahap dari kegiatan daur ulang yang dilakukan oleh masyarakat yang bekerja sebagai pemulung di RT 003 RW 001 Kelurahan Jurang Mangu Timur:

a) Mengumpulkan, yaitu mencari barangbarang bekas seperti gelas dan botol-botol plastik, kardus dan besi.

b) Memilah, yaitu mengelompokan sampah yang telah terkumpul berdasarkan 
jenisnya, seperti gelas, botol plastik, dan kardus.

c) Membersihkan, yaitu setelah dipilah-pilah barang pulungan dibersihkan terlebih dahulu.

d) Mengirim, yaitu barang bekas yang telah dibersihkan kemudian dikirim kepada bandar atau agen untuk ditimbang. Hal ini dilakukan setiap 2 minggu sekali.

Bandar atau pengepul adalah orang yang mempunyai modal untuk membeli beberapa jenis, atau satu jenis barang bekas dari pemulung. Bandar juga berperan menjual barang bekas ke industri atau pabrik. Jika barang bekas yang berhasil dikumpulkan pada satu periode sangat banyak bandar akan memberikan bonus atau tambahan uang kepada warga pemulung.

\section{Tingkat Pendapatan yang rendah}

Dalam memenuhi kebutuhan hidup sehari hari, manusia harus bekerja untuk memperoleh pendapatan agar kebutuhan hidupnya dapat terpenuhi. Menurut Tulus T.H Tambunan pendapatan artinya "pembayaran yang di dapat karena bekerja atau menjual jasa" (Tulus, 2003:97). Badan Pusat Statistik yang dikutip dalam Mulyadi menjelaskan indikator tingkat pendapatan sebagai berikut :

a) Rendah, kurang dari Rp 1.500 .000

b) Sedang, Rp1.500.000 - Rp 3.000.000

c) Menengah, $\operatorname{Rp} 3.000 .000-\operatorname{Rp} 5.000 .000$

d) Tinggi, lebih dari Rp 5.000.00 (Mulyadi, 2015:18)

Pada dasarnya, kemiskinan diidentifikasikan dengan taraf hidup yang rendah. Dapat diartikan pula sebagai suatu keadaan dimana penghidupan penduduk ditandai oleh serba kekurangan akan kebutuhan pokok. Menurut Widodo dalam M. Yani menjelaskan konsep kebutuhan dasar selalu dikaitkan dengan kemiskinan, penduduk misikin umumnya tidak berpenghasilan cukup. Penduduk miskin umumnya lemah dalam kebutuhan berusaha dan terbatas aksesnya pada kegiatan ekonomi sehingga tertinggal dengan masyarakat lainya (M Yani, 2016).

Berdasarkan temuan di lapangan bahwa warga pemulung merupakan warga yang berpindah tempat tinggal dari desa, diantaranya dari Madura, Bogor, Indramayu, Cirebon dan Sidoarjo. Warga yang berasal dari Sidoarjo merupakan korban bencana dari Lumpur Lapindo. Berdasarkan hasil wawancara warga hanya memperoleh pendapatan rata-rata sebesar Rp400.000,00 sampai Rp600.000,00 perbulan. $\mathrm{Hal}$ ini tergolong pada pendapatan rendah, karena menurut badan pusat statistik kategori pendapatan rendah yaitu kurang dari Rp1.500.000,00. Pendapatan ini diperoleh dari hasil mencari barang bekas, kemudian dibersihkan lalu ditimbang setiap 2 minggu sekali kepada agen pengepul sampah. Karena pendapatan yang terbilang rendah ini mereka tidak mampu mencukupi kebutuhan hidupnya sehari-hari seperti sandang, pangan dan papan.

Orang tua yang telah diwawancarai mengaku bahwa mereka mengalami kesulitan mengasuh anak dalam hal ekonomi. Mereka tidak cukup mampu memenuhi kebutuhan anak seperti sekolah, pakaian dan makanan bergizi. Sebagian besar anak keluarga pemulung tersebut disekolahkan di sekolah nonformal seperti di Homeschooling Kak Seto di Jalan Taman Makam Bahagia Abri No 3a Pondok Aren Tangerang Selatan.

\section{Orang Tua yang Mempekerjakan Anaknya}

Indonesia merupakan salah satu negara yang meratifikasi Konvensi Perserikatan BangsaBangsa (PBB) tentang hak-hak anak. Dengan diratifikasinya konvensi tersebut, berarti negara berkewajiban melindungi dan memenuhi hakhak anak. Akan tetapi pada kenyataanya, negara 
masih belum mampu memenuhi kewajiban untuk melindungi hak-hak anak. Salah satu yang menjadi permasalahan yang masih terjadi adalah keberadaan pekerja anak (Usman, N., 2004:1).

Menurut Badan Penelitian Pengembangan dan Informasi (2011) mendefinisikan anak adalah setiap anak yang berumur 18 tahun, sedangkan pekerja anak adalah penduduk yang bekerja dari umur 10 sampai dengan 17 tahun. Menurut Badan Pusat Statistik (2012) pekerja anak adalah usia anak yang bekerja usia 10-14 tahun yang melakukan pekerjaan dengan maksud memperoleh atau membantu memperoleh pendapatan atau keuntungan dengan lamanya bekerja paling sedikit satu jam seara kontinu (Badan Pusat Statistik, 2017). Pekerja anak adalah anak-anak yang melakukan pekerjaan secara rutin untuk orang tuanya atau orang lain dengan membutuhkan sejumlah besar waktu walaupun menerima imbalan atau tidak (Fery Fersafa A., 2014:25). Bukan hanya melanggar hak-hak anak, bekerja juga memberikan dampak buruk bagi anak. Baik secara fisik maupun psikis.

Menurut Irwanto dalam Usman, kemiskinan merupakan faktor mendasar terhadap munculnya pekerja anak. Sedangkan Bellamy dalam Usman mengatakan bahwa kekuatan yang paling kuat mendorong anakanak dalam lingkungan pekerjaan yang membahayakan dan melemahkan adalah eksploitasi terhadap kemiskinan (Usman, N., 2004:100).

Berdasarkan data penelitian Badan Pusat Statistik memperkirakan jumlah penduduk usia 10-14 tahun tahun sebanyak 20.640.950 jiwa. Dengan demikian jumlah pekerja anak di Indonesia pada tahun 2000 diperkirakan sebanyak 1.3394.824 jiwa (Usman, N., 2004:19).

Di Indonesia, kemiskinan menjadi penyebab utama anak-anak bekerja. Orang tua sangat membutuhkan tenaga anak-anaknya untuk membantu meningkatkan pendapatan rumah tangga. Asra (1993) dalam Usman mengemukakan bahwa $35 \%$ persen orang tua akan mengalami penurunan pendapatan rumah tangganya jika mereka berhenti bekerja. Sedangkan Imawan mengatakan bahwa 23,5\% pendapatan anak anak yang bekerja diberikan untuk orang tuanya. Hal ini disebabkan anakanak membutuhkan pekerjaan justru karena keadaan ekonomi keluarganya yang miskin (Usman, N., 2004:101).

Hal ini juga sejalan dengan hasil wawancara peneliti, bahwa faktor yang menyebabkan keluarga pemulung mempekerjakan anaknya adalah karena keadaan ekonomi keluarga yang miskin dan berpenghasilan rendah. Orang tua yang telah diwawancarai mengaku bahwa mereka mengalami kesulitan mengasuh anak dalam hal ekonomi. Mereka tidak cukup mampu memenuhi kebutuhan anak seperti sekolah, pakaian dan makanan bergizi.

Berdasarkan hasil wawancara peneliti, bahwa orang tua dari keluarga pemulung kerap memerintahkan anaknya untuk membantu mencari barang bekas seperti gelas dan botol air mineral, kardus dan juga besi. Tidak hanya itu orang tua juga kerap memerintahkan anaknya untuk mengamen dan menjual tisu, padahal anak yang dipekerjakan masih berusia 7 sampai 12 tahun. Setelah peneliti melakukan pengamatan selama 5 hari bahwa lokasi tempat tinggal mereka sepi di pagi harinya. Hal ini karena orang tua yang membawa anaknya bekerja, aktivitas ini dilakukan biasanya pada pukul 09.00 sampai pukul 12.00 WIB sebelum anak-anak berangkat ke sekolah.

Dalam sebuah keluarga idealnya ayah sebagai pencari nafkah, pelindung, pendidik dan pemberi rasa aman terhadap keluarganya. Sedangkan ibu berperan sebagai pengasuh, pendidik, dan pembimbing anak-anaknya. Pada Keluarga Pemulung tersebut terlihat bahwa 
mereka membawa anaknya bekerja sebagai pemulung bahkan mengamen dan menjual tisu. Padahal dalam keluarga, idealnya adalah ayah sebagai seorang suami dari istri yang seharusnya mencari nafkah dan bekerja, dan seharusnya anak hanya di fokuskan pada pendidikan. Hal ini juga melanggar Undang-Undang No 23 Tahun 2002 tentang perlindungan anak.

\section{Pola Asuh yang Diterapkan Orang Tua Terhadap Anak}

Pola asuh adalah upaya orang tua yang konsisten dan persisten dalam menjaga dan membimbing anak sejak dilahirkan hingga remaja. Pola asuh orang tua adalah pola yang diterapkan pada anak dan bersifat relatif konsisten dari waktu ke waktu. Pola perilaku ini dapat dirasakan oleh anak dan bisa memberi efek negatif maupun positif (Syaiful Bahri D, 2014:50).

Adapun menurut Elizabeth B Hurlock menjelaskan jenis jenis pola asuh sebagai berikut.

a) Otoriter, dalam pola asuhan ini orang tua memiliki kaidah kaidah dan peraturan peraturan yang kaku dalam mengasuh anaknya. Setiap pelanggaran dikenakan hukuman. Sedikit sekali atau tidak pernah ada pujian yang membenarkan tingkah laku anak apabila mereka melaksanakan aturan tersebut.

b) Demokratis, orang tua menggunakan diskusi, penjelasan dan alasan alasan yang membantu anak agar mengerti mengapa ia diminta untuk mematuhi suatu aturan. Orang tua menekankan aspek pendidikan ketimbang aspek hukuman. Hukuman tidak pernah kasar dan hanya diberikan apabila anak dengan sengaja menolak perbuatan yang harus ia lakukan. Apabila perbuatan anak sesuai dengan apa yang patut ia lakukan, orang tua memberi pujian. Orang tua yang demokratis adalah orang tua yang berusaha untuk menumbuhkan kontrol dari dalam diri anak sendiri.

c) Permisif, orang tua bersikap membiarkan atau mengizinkan setiap tingkah laku anak, dan tidak pernah memberikan hukuman kepada anak. Pola ini ditandai oleh sikap orang tua yang membiarkan anak mencari dan membiarkan sendiri tata cara yang memberi batasan batasan dari tingkah lakunya. Pada saat terjadi hal yang berlebihan barulah orang tua bertindak. Pada pola ini pengawasan menjadi sangat longgar (Bunga Rampai, 1999:52).

Berdasarkan temuan di lapangan diperoleh informasi bahwa orang tua dalam keluarga pemulung yang memiliki anak yang berusia 412 tahun tersebut kerap memberikan hukuman kepada anak, anak harus mematuhi peraturan yang diberikan orang tua, jika tidak patuh anak akan diberikan sanksi, tidak ada pujian apabila anak mematuhi perintah orang tua.

Pola asuh yang diterapkan orang tua dalam keluarga pemulung kepada anaknya adalah gaya yang membatasi dan menghukum dimana orang tua mendesak anak untuk mengikuti arahan mereka dan menghormati pekerjaan dan upaya mereka. Orang tua yang menerapkan batas dan kendali yang tegas pada anak orang tua mungkin juga sering memukul anak, memaksakan aturan secara kaku tanpa menjelaskannya dan menunjukan amarah pada anak.

Dari hasil wawancara peneliti, orang tua dalam keluarga pemulung mengaku kerap memberikan hukuman kepada anak jika anak tidak menuruti kemauan orang tua, hal ini dilakukan agar anak mau menuruti apa yang diinginkan orang tua, mereka juga jarang memberikan hadiah kepada anak mereka karena keterbatasan biaya hidup. Mereka pun jarang memberikan pujian kepada anak mereka. Padahal pujian perlu diberikan kepada anak, tujuannya adalah agar anak termotivasi untuk berperilaku sesuai dengan harapan orang tua. 
Dalam pola pengasuhan terdapat banyak faktor yang mempengaruhi dan melatar belakangi orang tua dalam menerapkan pola pengasuhan pada anaknya. Menurut Mindel dalam Agustiawati menyatakan bahwa ada beberapa faktor yang mempengaruhi pola pengasuhan salah satunya adalah faktor status sosial ekonomi. Dengan perekonomian yang cukup, kesempatan dan fasilitas yang diberikan serta lingkungan material yang mendukung cenderung mengarahkan pola asuh orang tua menuju perlakuan tertentu yang dianggap orang tua sesuai (Isni Agustiawati, 2014:19).

Hal ini sejalan dengan pendapat Maccoby dan Mcloyd yang telah membandingkan orang tua kelas menengah dan atas dengan kelas bawah atau pekerja dalam hal mengasuh anak. Hasilnya menunjukan bahwa orang tua kelas bawah cenderung sangat menekankan kepatuhan dan otoriter, lebih keras dan kurang bersifat hangat dan memberikan kasih sayang kepada anak (Syamsul Yusuf, 2012:53).

Menurut Becker, Deutsch, Kohn dan Sheldon tentang kaitan antara kelas sosial dengan cara atau teknik orang tua dalam mengatur, mengelola dan memperlakukan anak yaitu bahwa kelas bawah (Lower Class) cenderung lebih sering menggunakan hukuman fisik, kelas menengah (Middle Class) cenderung lebih memberikan pengawasan, dan perhatianya sebagai orang tua. Sedangkan kelas atas (Upper Class) cenderung lebih memanfaatkan waktu luangnya dengan kegiatan-kegiatan tertentu, lebih memiliki latar belakang pendidikan dan reputasi tinggi (Syamsul Yusuf, 2012:54).

Berdasarkan temuan di lapangan peneliti mendapatkan informasi bahwa tingkat pendapatan keluarga pemulung mempengaruhi pola asuh yang diterapkan. Pendapatan yang didapat keluarga pemulung rata-rata sebesar Rp.400.000 sampai Rp.600.000 perbulan, sehingga mereka tidak mampu mencukupi kebutuhan sehari hari. Karena pendapatan yang terbilang cukup sedikit ini mereka tidak memanjakan anak, mereka juga jarang menuruti kemauan anak. Bahkan mereka kerap mempekerjakan anak-anak mereka mencari barang pulungan seperti botol bekas air mineral, kardus dan besi.

Hal ini juga sejalan dengan penelitian yang dilakukan oleh Vera Widyastuti dari Universitas Negeri Yogyakarta yang menyatakan bahwa terdapat hubungan yang positif dan signifikan antara tingkat pendapatan orang tua terhadap pola asuh orang tua dengan nilai koefisien korelasi sebesar 0,411 dan nilai koefisiensi determinan sebesar 0,169 .

\section{Simpulan}

Berdasarkan hasil paparan data dan pembahasan sebagaimana telah diuraikan pada BAB sebelumnya, hasil penelitian ini adalah pola pengasuhan yang diterapkan keluarga pemulung terhadap anaknya yang berusia $4-12$ tahun di Kelurahan Jurang Mangu Timur adalah pola asuh otoriter, yaitu pola asuhan yang memiliki peraturan peraturan yang kaku dalam mengasuh anaknya. Setiap pelanggaran dikenakan hukuman. Sedikit sekali atau tidak pernah ada pujian yang membenarkan tingkah laku anak apabila mereka melaksanakan aturan tersebut.

Tingkat pendapatan yang rendah telah memengaruhi pola asuh yang diterapkan pada keluarga pemulung tersebut. Pendapatan yang didapat keluarga pemulung hanya sebesar 400.000.00 sampai 600.000 .00 setiap bulan, karena pendapatan yang rendah ini, mereka bahkan mempekerjakan anak anak mereka mencari barang pulungan. Mereka tidak memanjakan anak mereka dan juga jarang menuruti kemauan anak. 


\section{Daftar Pustaka}

Agustiawati, Isni, 2014, Pengaruh Pola Asuh Orang Tua terhadap Prestasi Belajar siswa pada Mata Pelajaran Akuntansi Kelas IX IPS Di SMA Negeri 26 bandung, Jurnal pada Universitas Pendidikan Bandung.

Badan Pusat Statistik, Pengertian Pekerja Anak, di akses pada tanggal 17 Februari 2017 https://bps.go.id/index.php/publikasi/346 $\underline{3}$

Balaka, M Yani, 2016, Faktor-Faktor Penyebab Kemiskinan Masyarakat Desa Kecamatan Lohia Kabupaten Muna, Jurnal Ekonomi.

Bunga Rampai, 1999, Sosiologi Keluarga , Jakarta : Yayasan Obor Indonesia.

Departemen Pendidikan dan Kebudayaan, Kamus Besar Bahasa Indonesia

Djamarah, Syaiful Bahri, 2014, Pola Asuh Orang Tua dan Komunikasi dalam keluarga, Jakarta : Rineka Cipta.

Fersafa, Fery, 2014, Analisis Variabel yang Mempengaruhi Curahan Waktu Kerja Pekerja Anak di Kabupaten Sleman, Skripsi, Universitas Diponegoro, Semarang.

Herdiyansyah, Haris, 2012, Metode Penelitian Kualitatif untuk Ilmu-ilmu Sosial, Jakarta: Salemba Humanika.

Lestari, Sri, 2012, Psikologi Keluarga, Jakarta:Kencana.

Mulyadi, 2015, Pengaruh Kondisi Sosial Ekonomi Terhadap Pengetahuan Masyarakat Akan dampak Konversi Lahan, Skripsi, UIN Jakarta.
Santrock, John W. , 2007, Perkembangan Anak Edisi Ketujuh, Jilid dua, Jakarta : Erlangga.

Setiono, Kusdwirarti, 2011, Psikologi Keluarga, Bandung: PT Alumni.

Sugiyono, 2014, Memahami Penelitian Kualitatif, Bandung : Alfabeta.

Sugiyono, 2012, Metode Penelitian Pendidikan (Pendekatan Kuantitatif, Kualitatif, dan $R \& D)$, Bandung: Alfabeta.

Sulistyaningsih, 2011, Metode Penelitian Kuantitatif Kualitatif, Yogyakarta:Graha Ilmu.

Taufik, Indra, 2013, Persepsi masyarakat terhadap pemulung di pemukinan TPA Bukit Pinang Samarinda, Jurnal.

Tulus T.H Tambunan, 2003, Perekonomian Indonesia, Jakarta : Ghalia Indonesia.

Undang Undang No 3 Tahun 1997 tentang Peradilan Anak

Undang Undang RI No.3 1997. Tentang Peradilan Anak.

Usman, Nachrowi, 2004, Pekerja Anak di Indonesia, Jakarta : PT Gramedia Widiasarana Indonesia.

Yusuf, Syamsul, 2012, Psikologi Perkembangan Anak dan Remaja, Bandung: PT Remaja Rosdakarya. 